\author{
볏짚 위주 사양 시 육성 흑염소의 농후사료 급여 수준이 발육, 사료이용성 \\ 및 경제성에 미치는 영향 \\ 김상우·김명직·김관우·김동훈·김영신 · 김 현·서상원·박성복* \\ 농촌진흥청 국립축산과학원, 남원, 590-832
}

\title{
Effect of Feeding Levels of Concentrate on the Growth, Feed Availability and Economic Evaluation in Feeds Based on Rice-straw of Growing Black Goats
}

\author{
Sang Woo Kim, Myeong Jik Kim, Kwan Woo Kim, Dong Hoon Kim, Young-Sin Kim, Hyun Kim, Sang won Suh \\ and Seong Bok Park*
}

Animal Genetic Resources Station, National Institute of Animal Science, RDA, Namwon 590-832, Korea

\begin{abstract}
This study investigates the effect of a feed concentrate on the growth performance, feed requirement, and rearing expenses of growing black goats. Forty female growing black goats were divided into four groups and fed rice straw (ad libitum) mixed with different levels of the feed concentrate: $\mathrm{T} 1(1.5 \%), \mathrm{T} 2(1.8 \%), \mathrm{T} 3(2.1 \%)$, and $\mathrm{T} 4(0 \%$, control). The average daily weight gain (body weight per day) was as follows: $\mathrm{T} 1<\mathrm{T} 2<\mathrm{T} 3<\mathrm{T} 4(50.23,60.37,71.46$ and $98.90 \mathrm{~g} /$ day, respectively) (p<0.05). The intake of rice straw decreased significantly with increase in the concentrate level $(\mathrm{p}<0.05)$. Rearing expenses amounted to 46,704, 49,998, 54,701 , and 74,613 won for feed concentrate levels of $1.5 \%, 1.8 \%, 2.1 \%$, and ad libitum, respectively. Increase in feed concentrate levels led to an increase in rearing expenses. In conclusion, a concentrate level of $2.1 \%$ was determined to be idea for a rice-straw-based feed for growing black goats.

(Key words : Growth, Feed availability, Economic evaluation, Growing black goat)
\end{abstract}

\section{I. 서 론}

우리나라의 흑염소는 예로부터 주로 중탕 위주의 약용 식품으로 소비되어왔으나 근래에 들어 건강식을 선호하는 소비자의 인식변화와 흑염소 고기전문 음식점이 성행함에 따라 육용 중심으로 소비가 더 많이 증가하고 있으며, 사 육두수 또한 증가하고 있다(Jeong et al., 2006). 과거 흑염 소 사육은 산야초와 농산부산물을 이용한 부업형태로 호당 10 두 미만이 사육되어 왔으나 최근 들어 대규모의 전업화 된 사육농가가 증가함으로서 효율적이고 체계적인 사양관 리가 필요한 실정이다. 이에 따라 흑염소 사료의 가치 평 가 및 사료의 이용효율을 높이기 위한 사료 급여체계에 대 한 연구가 활발히 진행되어 최근 흑염소의 사료가치 평가 Hwangbo et al., 2007)와 사료의 이용효율을 높이기 위한
사료급여체계에 대한 연구(Choi et al., 2006)가 활발히 수 행되고 있다.

그동안 국내 재래흑염소의 산육성은 성장단계, 성별 및 사육방법에 의해 차이가 있지만 일당증체량이 $50 \mathrm{~g}$ 내외 (Song et al., 1999), 33 49 (Jo et al., 2002), 40 45 (Hwang et al., 2006)에 불과하였다. 그러나 최근 흑염소의 산육성 개선을 위해 외래종 염소를 도입하여 교잡이 이루어진 상 태이다, 국내에 도입되어 교잡에 이용된 보아(Capra hircus) 종 염소는 다른 염소 품종에 비해 빠른 성장 속도를 가지 고 있는 것으로 알려져 왔다. 처음 12 개월 령까지의 일당 증체량이 $200 \mathrm{~g}$ 까지 자라며, 생후 $100,150,210$ 및 270 일 에 수컷은 각각 $291,271,245$ 및 $250 \mathrm{~g}$ 의 성장률을 보이 며, 암컷도 약 $272,249,204$ 및 $186 \mathrm{~g}$ 의 일당증체량을 나 타낸다고 하였다(Van Niekerk and Casey, 1988). 성축의 경

* Corresponding author: Seong Bok Park, Animal Genetic Resources Station, National Institute of Animal Science, R.D.A., Namwon 590-832, Jeonbuk, Korea, Tel: +82-63-620-3548, Fax: +82-63-620-3591, E-mail: psbbb@naver.com 
우 수컷은 90 130 kg, 암컷은 80 100 kg 정도 나간다고 보 고하였다( $\mathrm{Lu}$ and Potchoiba, 1988) 또한 국내에 도입되어 교잡에 이용되고 있는 호주산 야생염소(Australian feral goats : Capra aegagrus hircus)의 일당증체량은 $100 \mathrm{~g}$ 미만 이며, 성장이 완료되면 $60 \mathrm{~kg}$ 이 넘는 경우도 있다(Jago, 1999; Thompson et al., 1999). 무차별하게 교잡된 국내 교 잡흑염소의 일당증체량은 교잡정도에 따라 다르며, $\mathrm{Kim}$ et al. (2012)은 국내 교잡종 시험에서 일당증체량은 농후사료 자유채식 시 $100 \mathrm{~g}$ 정도라고 보고하였다.

현재 국내집약사육 염소농가의 경우는 조사료원은 대부 분 볏짚을 이용하고 있으며, 2010년 우리나라는 조사료 중 볏짚은 2,090천톤이 사료로 이용되고 있다(Ministry for food, agriculture, forestry and fisheries, 2011). 볏짚은 영양 적인 측면에서 섬유소, 리그닌 및 규산 함량이 높아 기호 성과 소화율이 낮고 조단백질 함량도 낮아 조사료 자원으 로 이용하기에는 빈약한 자원이지만 다른 조사료에 비해 가격이 저렴하고 구입이 용이하기 때문에 흑염소 농가에서 는 관행적으로 농후사료와 함께 조사료원으로 볏짚을 분리 급여하고 있으나, 흑염소에 대한 체계적인 급여수준은 아 직까지 구명되어 있지 않은 실정이다.

따라서, 본 연구에서는 육성기 흑염소에서 조사료원이 볏짚 단용인 경우 농후사료 급여수준에 따른 발육, 사료이 용성 및 경제성을 조사하여 육성 흑염소의 적정 사료급여 수준을 설정하고자 수행하였다.

\section{ㅍ. 재료 및 방법}

\section{1. 공시가축 및 사양관리}

본 시험에 공시된 공시가축은 성장속도 및 산육량 향상 을 위해 교잡화 된 4개월 령 암컷 흑염소 40두를 농가에서 구입하여 2주일간 예비시험을 실시한 후, 각 처리구별로 10 두씩을 공시하였다. 시험 장소는 전라북도 장수군 번암 면 소재 농가에서 수행하였으며, 시험기간은 2012년 5월 12 일부터 10 월 23 일까지 164 일간 수행하였다. 조사료인 볏 짚은 건조된 사각 베일러 볏짚을 세절하여 자유 채식 시켰 으며, 농후사료는 처리에 따라 체중의 $1.5 \%, 1.8 \%, 2.1 \%$ 및 자유채식구로 나누어 급여하였고 물은 자유 급수하여 충분히 음수토록 하였다.

\section{2. 시험설계 및 시험사료}

본 시험의 처리는 시판중인 흑염소 전용 농후사료를 체
중의 $1.5 \%(\mathrm{~T} 1), 1.8 \%(\mathrm{~T} 2$, 농가관행 $), 2.1 \%(\mathrm{~T} 3)$ 및 자유채 식구(T4)로 나누어 급여 하였고 조사료원은 볏짚을 자유채 식 하도록 하였으며 총 4 처리구로 나누어 처리구당 10 두씩 라틴방각법으로 실시하였고, 시험기간 동안 평균 30 일 간 격으로 체중을 측정하여 체중대비 농후사료 급여량을 조절 하였다. 시험사료의 화학적 조성분은 농후사료의 조단백질 함량은 $15.15 \%$, 조지방 함량은 $3.88 \%$, 조회분 함량은 6.75 $\%, \mathrm{TDN}$ 함량은 $68.00 \%$ 로 조사되었고, $\mathrm{ADF}$ 와 $\mathrm{NDF}$ 는 각 각 16.40 및 $39.02 \%$ 로 나타났다. 조사료 자원으로 급여된 볏짚의 일반성분은 조단백질 4.20 , 조지방 1.65 , 조회분 $11.50 \%$ 의 함량을 나타냈으며, $\mathrm{ADF}, \mathrm{NDF}$ 및 $\mathrm{TDN}$ 은 각각 44.27, 66.50 및 $39.70 \%$ 로 산출되었다(Table 1).

\section{3. 조사항목 및 방법}

1) 시험사료의 화학적 분석

시험사료 및 볏짚의 일반성분은 $\mathrm{AOAC} \mathrm{(1995)} \mathrm{법에} \mathrm{의해}$

Table 1. Ingredients and chemical composition of experimental diets

\begin{tabular}{lcc}
\hline \multirow{2}{*}{ Item } & \multicolumn{2}{c}{$\%$ of DM } \\
\cline { 2 - 3 } & Concentrate & Rice straw \\
\hline \hline Ingredients & 14.2 & - \\
Corn & 15.0 & - \\
Wheat & 19.3 & - \\
Wheat bran & 5.0 & - \\
Tapioca & 16.0 & - \\
Corn gluten feed & 7.0 & - \\
Coconut meal & 7.0 & - \\
Canola meal & 5.0 & - \\
Distillers grains & 9.5 & - \\
Palm kernel meal & 3.0 & - \\
Molasses & 1.1 & - \\
Limestone & 1.9 & - \\
Premix & 100 & - \\
Total & & \\
\hline Chemical composition & 11.50 & 11.55 \\
Moisture (\%) & 15.15 & 4.20 \\
Crude Protein (\%) & 3.88 & 1.65 \\
Crude Fat (\%) & 6.75 & 11.50 \\
Crude Ash (\%) & 16.40 & 44.27 \\
ADF (\%) & 39.02 & 66.50 \\
NDF (\%) & 68.00 & 39.70 \\
TDN (\%) & & \\
\hline
\end{tabular}

ADF : Acid detergent fiber, NDF: Neutral detergent fiber, TDN : Total digestible nutrients. 
분석하였고 $\mathrm{ADF}$ 와 $\mathrm{NDF}$ 함량은 Goering and Van Soest (1970)의 방법에 의해 분석하였다.

\section{2) 사료 섭취량 및 체중}

사료 및 볏짚 섭취량은 급여한 양과 섭취하고 남은 양의 차이로 구하였으며, 잔량은 다음날 오전 사료 급여 전에 수거하여 측정하였다. 체중조사는 시험 개시일 부터 종료 까지 30 일 간격으로 오전 사료급여 전에 측정 하였으며, 증체량은 종료 시 체중에서 개시 체중을 뺀 값으로 계산하 였다.

\section{3) 경제성 분석}

경제성 분석은 육성기 동안의 경영비를 계산하여 비교하 였으며 본 시험에 이용한 볏짚은 구입가격인 $1 \mathrm{~kg}$ 당 220 원, 농후사료가격은 큰염소 전용사료(대한사료)의 구입가격인 $\mathrm{kg}$ 당 560 원으로 고정하여 분석하였다. 본 시험의 결과는 육성기 동안의 두당 경영비 개념으로 분석을 하였다.

\section{4. 통계분석}

본 시험에서 얻어진 모든 자료들의 결과는 Statistical Analysis System (SAS release ver 9.1, 2002)의 General linear model (GLM) procedure를 이용하여 분산분석을 실시 하였으며, 처리 간 유의성은 Duncan's multiple range test (5\% 수준)를 이용하여 검정하였다(Duncan, 1955)

\section{III. 결과 및 고찰}

\section{1. 증체량}

볏짚 위주의 사양 시 육성기 흑염소의 농후사료 급여수 준에 따른 개시 시 체중은 $\mathrm{T} 1(1.5 \%), \mathrm{T} 2(1.8 \%), \mathrm{T} 3(2.1 \%)$
및 $\mathrm{T} 4$ (자유채식)구가 각각 $11.92,11.89,11.88$ 및 $11.93 \mathrm{~kg}$ 이었고 종료 시 체중은 T1 $(1.5 \%), \mathrm{T} 2(1.8 \%), \mathrm{T} 3(2.1 \%)$ 및 $\mathrm{T} 4$ (자유채식)구가 각각 $20.64,21.79,23.60$ 및 $28.15 \mathrm{~kg}$ 으로 $\mathrm{T} 4$ (자유채식)구가 농후사료 급여수준을 달리한 $\mathrm{T} 1$ (1.5\%), $\mathrm{T} 2 \quad(1.8 \%)$ 및 $\mathrm{T} 3(2.1 \%)$ 구 보다 유의적으로 높았으며 $(\mathrm{p}<0.05), \mathrm{T} 4$ (자유채식)구를 제외한 농후사료 급여수준별로 비교하였을 경우, 처리구간에 유의차는 없었으나, 농후사료 급여수준이 높은 $\mathrm{T} 3(2.1 \%)$ 구가 높은 경향을 보였다. 일당 증체량은 $\mathrm{T} 1(1.5 \%), \mathrm{T} 2(1.8 \%), \mathrm{T} 3(2.1 \%)$ 및 $\mathrm{T} 4$ (자유채식) 구가 각각 $50.23,60.37,71.46$ 및 $98.90 \mathrm{~g}$ 으로 농후사료의 급여 수준이 높아질수록 유의하게 높았다 $(\mathrm{p}<0.05)$ (Table 2). 보통 육성기 염소 사육에 있어서 가장 중요한 것은 첫 종부시기에 적정 체중에 도달해야하며 일반적으로 첫 종부 시기에 체중은 성숙한 암컷 체중의 $40 \sim 70 \%$ 정도이다 (Yami and Merkel, 2008). 하지만 국내에서는 일반적으로 육성기 흑염소 암컷의 첫 종부시기가 10 개월 령에 체중 20 $\mathrm{kg}$ 이상에서 종부를 시킨다(Choi, 2007). 본 시험 결과, 육 성기 자유채식구는 8 개월 령 이전에 적정종부 체중인 20 $\mathrm{kg}$ 에 도달하였으나, 이 시기는 이직 적정 종부월령이 되지 못한 시기이며, 또한 $\mathrm{T} 1(1.5 \%)$ 구와 $\mathrm{T} 2(1.8 \%)$ 구는 8 개월 령에 적정 종부체중인 $20 \mathrm{~kg}$ 에 도달하지 못하였다. 가축의 성성숙은 기후 및 여러 가지 환경조건에 따라 영향을 받고 영양상태에 따라서도 지배를 받으며, 염소의 성성숙 도달 월령은 6 8 개월 령으로 조사료원이 볏짚 위주인 경우 육 성기 흑염소의 농후사료(CP: $15 \%, \mathrm{TDN} 68 \%$ ) 급여 수준은 체중의 $2.1 \%$ 를 급여하는 것이 바람직한 것으로 사료된다.

\section{2. 사료섭취량}

볏짚 위주의 사양 시 육성기 흑염소의 농후사료 급여수 준에 따른 1 일 $\mathrm{DM}$ 섭취량은 $\mathrm{T} 1(1.5 \%), \mathrm{T} 2(1.8 \%), \mathrm{T} 3$ (2.1\%) 및 $\mathrm{T} 4$ (자유채식)구가 각각 $475,489,528$ 및 $713 \mathrm{~kg}$

Table 2. Effect of feeding levels on performance in growing black goats

\begin{tabular}{lcccc}
\hline \multirow{2}{*}{ Items } & \multicolumn{4}{c}{ Treatments $^{1)}$} \\
\cline { 2 - 5 } & $\mathrm{T} 1$ & $\mathrm{~T} 2$ & $\mathrm{~T} 3$ & $\mathrm{~T} 4$ \\
\hline \hline Initial body wt., $\mathrm{kg}(4 \mathrm{mo})$. & $11.92 \pm 2.29$ & $11.89 \pm 2.31$ & $11.88 \pm 2.40$ & $11.93 \pm 2.27$ \\
Finial body wt., $\mathrm{kg}(9 \mathrm{mo})$ & $20.64 \pm 3.54^{\mathrm{b}}$ & $21.79 \pm 3.03^{\mathrm{b}}$ & $23.60 \pm 3.38^{\mathrm{b}}$ & $28.15 \pm 4.16^{\mathrm{a}}$ \\
Total weight gain, $\mathrm{kg}$ & $8.24 \pm 2.58^{\mathrm{c}}$ & $9.90 \pm 2.31^{\mathrm{bc}}$ & $11.72 \pm 2.16^{\mathrm{b}}$ & $16.22 \pm 2.62^{\mathrm{a}}$ \\
ADG (g/day) & $50.23^{\mathrm{c}}$ & $60.37^{\mathrm{bc}}$ & $71.46^{\mathrm{b}}$ & $98.90^{\mathrm{a}}$ \\
\hline
\end{tabular}

\footnotetext{
${ }^{1)}$ Concentrate feed level/body weight $; \mathrm{T} 1=1.5 \%, \mathrm{~T} 2=1.8, \mathrm{~T} 3=2.1, \mathrm{~T} 4=$ ad libitum feeding.

${ }^{2)}$ ADG : Average daily gain.

${ }^{a b c}$ Values with different superscripts in row are significantly different $(p<0.05)$.
} 
으로 농후사료 급여수준이 증가할수록 증가하였으나, 볏짚 의 섭취량은 $\mathrm{T} 1(1.5 \%), \mathrm{T} 2(1.8 \%), \mathrm{T} 3(2.1 \%)$ 및 $\mathrm{T} 4$ (자유채 식)구가 각각 $226,191,170$ 및 $118 \mathrm{~g}$ 으로 농후사료 급여 수준이 증가할수록 유의적으로 감소하였다 $(\mathrm{p}<0.05)$ (Table 3). 이는 조사료 섭취량은 저에너지 사료보다 고에너지 사 료 급여시 감소한다는 Ahn et al.(1991)의 보고 및 볏짚위 주 사양 시 비육 흑염소 경우에도 사료섭취량은 농후사료 의 급여수준이 증가할수록 감소하였다는 Kim et al. (2012) 의 보고와 유사한 결과를 보였으며, 또한 육성기 흑염소에 있어서 조사료의 품질이 낮을 경우, 장내 체류 시간이 길 어져 사료섭취량이 감소한다는(Lippke, 1980) 보고로 보아 볏짚의 섭취량을 감소시키는 한 요인으로 작용되었을 것으 로 사료된다. 사료섭취량을 증체량으로 나누어 나타낸 사 료 요구율은 $\mathrm{T} 1(1.5 \%), \mathrm{T} 2(1.8 \%), \mathrm{T} 3(2.1 \%)$ 및 $\mathrm{T} 4$ (자유채 식)구가 각각 $9.46,8.10,7.39$ 및 7.21으로 농후사료 급여 수준이 증가할수록 낮아졌다 $(\mathrm{p}<0.05)$. 하지만 $\mathrm{T} 1(1.5 \%)$ 구와 $\mathrm{T} 2(1.8 \%)$ 구의 사료요구율이 높았던 이유는 전체적인 $\mathrm{DM}$ 섭취량이 $\mathrm{T} 3(2.1 \%)$ 구와 $\mathrm{T} 4$ (자유채식)구보다 낮아서 나타난
결과로 보인다.

\section{3. 경제성 분석}

볏짚 위주 사양 시 육성기 흑염소에 대한 농후사료 급여 수준별 경제성 분석 결과는 Table 4와 같다. 경제성 분석 은 육성기간 동안의 경영비만을 분석하였다. 경영비 중 조 사료 가격은 볏짚의 유통가격인 $\mathrm{kg}$ 당 220 원으로 고정하여 계산하였으며, 농후사료 가격은 흑염소 펫렛 사료(대한사 료)의 판매가격인 $\mathrm{kg}$ 당 560 원으로 각각 계산하였다.

경영비는 농후사료를 $1.5 \%(\mathrm{~T} 1), 1.8 \%(\mathrm{~T} 2), \mathrm{T} 3(2.1 \%)$ 및 자유채식(T4) 하였을 때 각각 46,704원, 49,998원, 54,701원 및 74,613원으로 농후사료의 급여수준이 증가할수록 경영 비는 높았다. 하지만 $\mathrm{T} 4$ (자유채식)구의 경우, 증체량은 다 른 처리구에 비해 가장 많이 증가하였으나 사료비가 $\mathrm{T} 3$ (2.1\%)구보다 두당 19,912 원 더 많이 들었다. 이상의 시험 결과를 종합하여 고려할 때, 육성기에 과다한 영영섭취는 이후 출산률을 감소시키며 유선의 발달을 저해하는 점을

Table 3. Effect of feeding levels on feeding availability in growing black goats

\begin{tabular}{|c|c|c|c|c|}
\hline \multirow{2}{*}{ Items } & \multicolumn{4}{|c|}{ Treatments } \\
\hline & $\mathrm{T} 1^{1)}$ & $\mathrm{T} 2$ & T3 & $\mathrm{T} 4$ \\
\hline " TDMI (g/day) ${ }^{2}$ & $475^{\mathrm{d}}$ & $489^{c}$ & $528^{\mathrm{b}}$ & $713^{\mathrm{a}}$ \\
\hline - Concentrate & $249^{d}$ & $299^{c}$ & $358^{\mathrm{b}}$ & $595^{\mathrm{a}}$ \\
\hline - Rice straw & $226^{\mathrm{a}}$ & $191^{\mathrm{b}}$ & $170^{\mathrm{c}}$ & $118^{\mathrm{d}}$ \\
\hline $\begin{array}{l}\text { Feed conversion } \\
\text { TDMI/ADG }(\mathrm{kg} / \mathrm{kg})\end{array}$ & $9.46^{\mathrm{a}}$ & $8.10^{\mathrm{b}}$ & $7.39^{c}$ & $7.21^{\mathrm{d}}$ \\
\hline
\end{tabular}

${ }^{1)}$ Concentrate feed level/body weight $; \mathrm{T} 1=1.5 \%, \mathrm{~T} 2=1.8, \mathrm{~T} 3=2.1, \mathrm{~T} 4=$ ad libitum feeding.

2) TDMI : Total dry matter intake.

abcd Values with different superscripts in row are significantly different $(\mathrm{p}<0.05)$.

Table 4. Economic analysis for production of growing black goats in different feeding levels

\begin{tabular}{lcrrr}
\hline \multirow{2}{*}{ Items } & \multicolumn{3}{c}{ Treatments } \\
\cline { 2 - 5 } & \multicolumn{1}{c}{ T1 $^{1)}$} & T2 & T3 & Control \\
\hline \hline Operating expense (Won) & 46,704 & 49,998 & 54,701 & 74,613 \\
- Concentrates & 22,851 & 27,423 & 32,854 & 54,667 \\
- Roughage & 8,153 & 6,875 & 6,147 & 4,246 \\
- Medicine & 2,000 & 2,000 & 2,000 & 2,000 \\
- Others & 13,700 & 13,700 & 13,700 & 13,700 \\
- Ratio(\%) & 62.5 & 67.0 & 73.3 & 100 \\
\hline
\end{tabular}

\footnotetext{
${ }^{1)}$ As given in Table 1

Concentrate feed price : $560 \mathrm{Won} / \mathrm{kg}$, Roughage price : $220 \mathrm{Won} / \mathrm{kg}$.
} 
감안하고, $\mathrm{T} 3(2.1 \%)$ 구가 8 개월에 적정 번식체중인 $20 \mathrm{~kg}$ 을 넘었으므로 육성기 흑염소에 있어서 조사료 원이 볏짚 단 용일 경우에는 농후사료(CP: $15 \%, \mathrm{TDN} 68 \%$ ) 를 체중의 $2.1 \%$ 급여하는 것이 가장 바람직할 것으로 사료 된다.

$$
\text { IV. 요 약 }
$$

본 시험은 육성기 흑염소에 있어서 조사료원이 볏짚 위 주일 때, 농후사료 급여 수준이 발육, 사료이용성 및 경제 성에 미치는 영향을 구명하기 위해 실시하였다. 육성기 암 컷 흑염소 40 두를 공시하여 농후사료 급여수준을 체중의 $1.5 \%(\mathrm{~T} 1), 1.8 \%(\mathrm{~T} 2), 2.1 \%(\mathrm{~T} 3)$ 및 자유채식구 $(\mathrm{T} 4)$ 로 나누 어 급여 하였고 조사료원은 볏짚을 자유채식 하도록 하였 다. 그 결과, 일당 증체량은 $\mathrm{T} 1(1.5 \%), \mathrm{T} 2(1.8 \%), \mathrm{T} 3$ $(2.1 \%)$ 및 $\mathrm{T} 4$ (자유채식)구가 각각 $50.23,60.37,71.46$ 및 $98.90 \mathrm{~g}$ 으로 농후사료의 급여 수준이 높아질수록 유의하게 높았으며 $(\mathrm{p}<0.05)$, 조사료인 볏짚의 사료 섭취량은 농후사 료 급여수준이 증가 할수록 유의적으로 감소하는 결과를 보였다 $(\mathrm{p}<0.05)$. 경제성 분석에 있어서 육성기 흑염소 경영 비는 농후사료를 $1.5 \%, 1.8 \%, 2.1 \%$ 및 자유 채식하였을 때 각각 46,704원, 49,998원, 54,701원 및 74,613원으로 농후사 료의 급여수준이 증가할수록 경영비는 증가하였다. 이는 증체량에 있어서 $\mathrm{T} 4$ (자유채식)구가 가장 많이 증가하였지 만 T3 (2.1\%)구보다 사료비에 있어서 두당 19,912원 더 많 이 들었다. 이상의 시험 결과를 종합하여 고려할 때, 육성 기 흑염소에 있어서 조사료 원이 볏짚 단용일 경우에는 농 후사료를 $2.1 \%$ 수준으로 급여하는 것이 가장 바람직할 것 으로 사료 된다.

$$
\mathrm{V} \text {. 사 사 }
$$

본 연구는 농촌진흥청 공동연구사업(PJ009430) 지원에 의해 수행되었다.

\section{REFERENCES}

Ahn, B.H., Lee, B.O. and Kwack, J.H. 1991. Effect of Energy Levels on Performance of Korean Native Goat. Korean Journal of Animal Nutrition and Feed. 15:321-329.

AOAC. 1995. Official Methods of Analysis. $16^{\mathrm{TH}}$ ed. Association of Offcial Analytical Chemists. Washington, DC

Choi, S.H. and Choi C.Y. 2007. Black goat breeding.

Choi, S.H., Hwangbo, S., Kim, S.W., Sang, B.D., Kim, Y.K. and Jo,
I.H. 2006. Effects of Total Mixed Ration with Wet Brewer's Grain on the Performance and Nutrient Utilization in Castrated Korean Black Goats. Journal of The Korean Society of Grassland and Forage Science. 26:199-206.

Duncan, B. D. 1955. Multiple Range and Multiple F test. Biometrics. 11:1-10.

Goering, H.K. and Van Soest, P.K. 1970. Forage Fiber Analysis. USDA Agric. Handbook No. 379: Washington, D.C.

Hwangbo, S., Jo, I.H., Song, K.J. and Lee, S.H. 2007. Effects of Dietary Probiotics on Feed Intakes, Nutrient Digestibility and Nitrogen Retention in Korean Black Goats Fed Two Diets Differing in Forage to Concentrate Ratios. Korean Journal of organic agriculture. 15:195-205.

Hwangbo, S., Jo, I.H., Lee, S.H. and Kim, S.K. 2006. Effect of Acanthopanax Senticosus Leaves Supplementation on Performance, Nutrient Digestibility and Blood Characteristics in Korean Black Goats. Journal of the Korean Society of Grassland and Forage Science. 26:239-248.

Jago, B. 1999. Feral goat (Capra hircus) in Queensland. In Pest status review series- land protection(p.2). Department of Natural Resource and Mines. QLD Government.

Jeong, C.H., Seo, K.I. and Shin, K.H. 2006. Effects of Fermented Grape Feeds on Pyhsico-Chemical Properties of Korean Goat Meat. Journal of The Korean Society of Food Science and Nutrition. 35:145-149.

Jo, I.H. 2002. Feeding and Management of organic black goat. Gyeongsangbuk-do Agriculture research \& Extension services.

Kim, S.W., Yoon, S.H., Kim, J.H., Ko, Y.G., Kim, D.H., Kang, G.H., Kim, Y.S., Lee, S.M. and Suh, S.W. 2012. Effects of Feeding Levels of Concentrate on the Growth, Carcass Characteristics and Economic Evaluation in Feeds Based on Rice-straw of Korean Black Goats. Journal of the Korean Society of Grassland and Forage Science. 32:429-436.

Lippke, H. 1980. Forage characteristics related to intake, digestibility and gain by ruminants. Journal of Animal Science. 50:952-961.

Lu, C.D. and Potchoiba. 1988. Milk feeding and weaning of goat kids. Small Ruminant Research. 1:105-112.

Ministry for Food, Agriculture, Forestry and Fisheries. 2011. Roughage product and utilization technology textbook.

Thompson, J., Riethmuller, J., Kelly, D., Boyd-Law, S. and Miller, E. 1999. Feral goat management in South-West Queensland-Final Report to the Bureau of Rural Sciences. Queensland Department of Natural Resources and Mines, Brisbane.

SAS Institute Inc 2002 SAS/STAT User's Guide: Version 8.2 SAS Institute Inc., Cary Norh Carolina USA. 
Do, J.C. and Lim, H.S. 1999. Study on improve the income of farm of goat breeding. Ministry of Agriculture and Forestry.

Van Niekerk, W.A. and Casey, N.H. 1988. The Boer goat. II. Growth, nutrient requirements, carcass and meat quality. Small Rumin. Res. 1:355-368.
Yami, A. and Merkel, R.C. 2008. Sheep and Goat Production Handbook for Ethiopia. Ethiopia Sheep and Goat productivity Improvement Program. pp. 103-160.

(Received October 22, 2013/Revised November 18, 2013/Accepted November 20, 2013) 